\title{
EDITORIAL
}

\section{In Memory of Professor Robert E. Slavin}

\author{
Alan C. K. Cheung
}

$\mathrm{R}$

OBERT E. SLAVIN, a world-recognized education researcher, passed

away on April 24, 2021. The unfortunate death of Professor Slavin was a great loss for the global educational research, especially for our journal.

Holding positions as a research scientist, the first-ever Distinguished Professor at the Johns Hopkins School of Education, and director of the Johns Hopkins Center for Research, and Reform in Education, Dr. Slavin sought to translate the science of learning into effective teaching practices (Myers, 2021). Professor Slavin was among the earliest researchers working on cooperative learning, an approach through which small teams of students with different academic abilities work together (Roberts, 2021). These are now used throughout the world

As the preeminent researcher in the field of education, he always concentrated on the up-to-date education issues, devoting himself to the journey of promoting better education to the students in need. "What most studies show is that mixed-ability grouping doesn't hurt high-achieving students and in fact helps those of lower achievement levels," Dr. Slavin told The New York Times in 1990 (Smothers, 1990).

Professor Slavin was the chief expert of the School of Education at Johns Hopkins University. He led the College of Education and achieved first place in the National Education College Rankings (2014-2016). Professor Slavin was the top-ten influential scholar in the field of education research in the United States. He has published more than 300 articles and two dozen books, exploring topics including classroom organization, school desegregation, cooperative learning, and evidence-based reform, and has made outstanding contributions to educational research and public service (Smith, 2021).

Professor Slavin is perhaps the world's most effective advocate for using evidence as a basis for educational policy and practice. He has published dozens of reviews of research on effective practices in elementary and sec-

(C) 2021 Insights Publisher. All rights reserved.

Creative Commons Non Commercial CC BY-NC: This article is distributed under the terms of the Creative Commons Attribution-NonCommercial 4.0 License

(http://www.creativecommons.org/licenses/by-nc/4.0/) which permits non-commercial use, reproduction and distribution of the work without further permission provided the original work is attributed by the Insights Publisher. 
ondary reading, writing, mathematics, science, and early childhood education (see www.bestevidence.org), and has written widely on methodology for research review. To make evidence on educational effectiveness available to all, he founded two free websites for educators and researchers, the Best Evidence Encyclopedia (www.evidenceforessa.org) (mostly for researchers) and Evidence for ESSA (www.evidenceforessa.org) (mostly for educators). $\mathrm{He}$ also wrote weekly blogs on evidence-based reform in education, and distributed a bi-weekly online summary of recent research and policy developments, i.e., Best Evidence in Brief (BEiB).

Meanwhile, Professor Slavin also contributed to the establishment of the corresponding platform supported by the Institute for Effective Education (IEE) at the University of York in the U.K. (http://www.beib.org.uk/), and the Centre for University \& School Partnership at the Chinese University of Hong Kong in China (https://cuspbeb.com/). During his visit to China in 2018, he signed cooperation with the School of Education of Nanjing Normal University to establish the simplified Chinese version of the education evidence-based research "Best Evidence in Brief" and served as the director of the editorial board (http://www.cnbeb.org.cn:81/en/). In the form of a "newsletter", it has built a bridge for the exchanges between the world and China in the field of evidence-based research in education (Li \& Yao, 2018). These platforms provide convenient results of the optimum evidence-based research results, so as to help worldwide educational scholars with professional support better improve the current evidence-based education (Slavin et al., 2021).

The educational research achievements of Professor Slavin were the valuable fortune of the world educational research, in memory of his remarkable achievements, in order to inherit his research results, and for the further development of the evidence-based research, we hereby published the "Professor Slavin and the development of evidence-based education in China" and "Success for All: Professor Slavin and the improvement of evidencebased schools and its enlightenment to China" written by the editorial board members (Yao, 2021) and (Zhou \& Gu, 2021), respectively. Affected by the limitations such as time, these articles could be insufficient in structure and methods, but it will not have any impact on the memory of Professor Slavin or lower the quality of the journal.

\section{References}

Li, M., \& Yao, J. (2018). Professor R. E. Slavin from Johns Hopkins University visited our school. Nanjing Normal University. [Chinese] Retrieved May 19, 2021, from http://www.njnu.edu.cn/info/1038/8578.htm 
Myers, A. (2021). Robert Slavin, global authority on education research and evidence-based school reform, dies at 70. Hub at Johns Hopkins. Retrieved May 18, 2021, from https://hub.jhu.edu/2021/04/26/robertslavin-obituary/

Roberts, S. (2021). Robert Slavin, who studied how children learn, dies at 70. The New York Times. Retrieved May 19, 2021, from https://www.nytimes.com/2021/05/11/education/robert-slavindead.html

Slavin, R., Cheung, A., \& Zhuang, T. (2021). How does evidence-driven education reform promote education development. Journal of East China Normal University (Education Science Edition), 2021, 39(3):14-22. [Chinese] DOI: https://doi.org/10.16382/j.cnki.10005560.2021.03.002

Smith, H. (2021). Robert Slavin, whose reading program is used in schools nationwide, dies at 70. The Washington Post. Retrieved May 19, 2021, from https://www.washingtonpost.com/local/obituaries/robert-slavindead/2021/04/28/275a5792-a7aa-11eb-8c1a-56f0cb4ff3b5 story.html

Smothers, R. (1990). THE NATION: In pupil 'Tracks,' many see a means of resegregation. The New York Times. Retrieved May 19, 2021, from https://www.nytimes.com/1990/02/18/weekinreview/the-nation-inpupil-tracks-many-see-a-means-of-resegregation.html

Yao, J. (2021). Professor Slavin and the development of evidence-based education in China. Best Evidence in Chinese Education, 8(1):1021-1028. DOI: https://doi.org/10.15354/bece.21.or30

Zhou, L., \& Gu, H. (2021). Success for all: Professor Slavin and the improvement of evidence-based schools and its enlightenment to China. Best Evidence in Chinese Education, 8(1):1029-1040. DOI: https://doi.org/10.15354/bece.21.or35

Correspondence to: Alan C. K. Cheung, Ph.D. Department Chairperson and Professor Department of Educational Administration and Policy The Chinese University of Hong Kong Hong Kong 999077 China Email: alancheung@cuhk.edu.hk 